\title{
Plasma Concentrations and Subcutaneous Adipose Tissue mRNA Expression of Clusterin in Obesity and Type 2 Diabetes Mellitus: the Effect of Short-Term Hyperinsulinemia, Very-Low-Calorie Diet and Bariatric Surgery
}

\author{
J. KLOUČKOVÁ ${ }^{1}$, Z. LACINOVÁ ${ }^{1,2}$, P. KAVÁLKOVÁ ${ }^{1}$, P. TRACHTA ${ }^{2}$, M. KASALICKÝ ${ }^{3}$, \\ D. HALUZÍKOVÁ ${ }^{4}$, M. MRÁZ ${ }^{2}$, M. HALUZÍK ${ }^{1,5}$
}

${ }^{1}$ Institute of Medical Biochemistry and Laboratory Diagnostics, First Faculty of Medicine, Charles University and General University Hospital, Prague, Czech Republic, ${ }^{2}$ Third Department of Medicine, First Faculty of Medicine, Charles University and General University Hospital, Prague, Czech Republic, ${ }^{3}$ Department of Surgery, Second Faculty of Medicine, Charles University and Military University Hospital, Prague, Czech Republic, ${ }^{4}$ Department of Sports Medicine, First Faculty of Medicine, Charles University and General University Hospital, Prague, Czech Republic, ${ }^{5}$ Institute of Endocrinology, Prague, Czech Republic

Received July 2, 2015

Accepted January 8, 2016

On-line April 12, 2016

\section{Summary}

Clusterin is a heterodimeric glycoprotein with wide range of functions. To further explore its possible regulatory role in energy homeostasis and in adipose tissue, we measured plasma clusterin and its mRNA expression in subcutaneous adipose tissue (SCAT) of 15 healthy lean women, 15 obese women (OB) and 15 obese women with type 2 diabetes mellitus (T2DM) who underwent a 2-week very low-calorie diet (VLCD), 10 obese women without T2DM who underwent laparoscopic sleeve gastrectomy (LSG) and 8 patients with T2DM, 8 patients with impaired glucose tolerance (IGT) and 8 normoglycemic patients who underwent hyperinsulinemic euglycemic clamp (HEC). VLCD decreased plasma clusterin in OB but not in T2DM patients while LSG and HEC had no effect. Clusterin mRNA expression in SCAT at baseline was increased in $\mathrm{OB}$ and T2DM patients compared with controls. Clusterin mRNA expression decreased 6 months after LSG and remained decreased 12 months after LSG. mRNA expression of clusterin was elevated at the end of HEC compared with baseline only in normoglycemic but not in IGT or T2DM patients. In summary, our data suggest a possible local regulatory role for clusterin in the adipose tissue rather than its systemic involvement in the regulation of energy homeostasis.

\section{Key words}

Clusterin - Subcutaneous adipose tissue - Obesity • Bariatric surgery $\bullet$ Very-low-calorie diet

\section{Corresponding author}

M. Haluzík, Department of Obesitology, Institute of Endocrinology, Národní 8, 11694 Prague 1, Czech Republic. Fax: + 420 224905325. E-mail: mhalu@lf1.cuni.cz

\section{Introduction}

Clusterin, also known as apolipoprotein $\mathrm{J}$ (ApoJ), sulfated glycoprotein-2 (SGP-2), SP 40,40 and under numerous other names, is a heterodimeric glycoprotein with a molecular weight of 70-80 kDa. It was isolated for the first time in 1983 as a protein capable of aggregation of Sertoli cells to clusters (Blaschuk et al. 1983, Fritz et al. 1983). Clusterin is expressed by most of the tissues and is present also in plasma, breast milk, cerebrospinal fluid and semen (Aronow et al. 1993, ChoiMiura et al. 1992, Kounnas et al. 1995). Clusterin has multiple functions including those in lipid transport, complement inhibition, regulation of sperm maturation, inflammation, cell migration and apoptosis (Jenne et al. 
1991, Trougakos et al. 2002). Its higher levels are associated with Alzheimer dementia, type 2 diabetes mellitus, metabolic syndrome and cardiovascular diseases (Song et al. 2012, Trougakos et al. 2002). Nevertheless, its main function still remains to be defined. It is possible that clusterin has either multiple different independent functions in the body or it may have some universal regulatory function such as acting as a chaperon protecting cells in different tissues from stress (Humphreys et al. 1999).

Approximately $40-60 \%$ of circulating clusterin is bound to apolipoprotein A-I as a part of the high density lipoprotein (HDL) (James et al. 1991, Jenne et al. 1991); however, it can also be part of low or very low density lipoprotein (LDL, VLDL) (Hoofnagle et al. 2010, Pettersson et al. 2011). Clusterin also creates binding complexes with leptin which could be part of the HDL or non-lipoprotein part of blood serum (Bajari et al. 2003). In in vitro studies, clusterin-leptin complex is able to bind to both leptin and LDL receptors (Bajari et al. 2003). Therefore, it has been suggested that clusterin could act as a regulator of leptin activity (Bajari et al. 2003). Nevertheless, other data do not support such conclusion. For example: Arnold and colleagues (2011) have shown that in the group of obese adolescents before and after weight reduction only $1 \%$ of serum leptin was bound to clusterin or HDL and that there were no correlations between serum clusterin and leptin. Poulakou and colleagues (2008) even found an inverse relationship between serum clusterin and leptin or HDL, respectively, in patients with coronary heart disease. No clear relationship was identified between BMI and serum clusterin levels (Arnold et al. 2011, Kujiraoka et al. 2006, Poulakou et al. 2008). Nevertheless, weight loss induced both by hypocaloric diet and laparoscopic gastrectomy was found to lower serum clusterin levels in some studies (Arnold et al. 2011, Oberbach et al. 2011).

Information on the possible role of clusterin in the regulation of adipose tissue function or in the etiopathogenesis of type 2 diabetes mellitus (T2DM) is conflicting. While in some studies patients with T2DM had higher plasma clusterin concentrations which positively correlated with plasma glucose levels (Kujiraoka et al. 2006, Trougakos et al. 2002), in another study no difference in clusterin levels between healthy and diabetic patients was found (Poulakou et al. 2008). T2DM patients had also a lower percentage of clusterin in HDL (Hoofnagle et al. 2010) and higher clusterin percentage in LDL particles (Pettersson et al. 2011) compared with healthy controls. Considering the possible cardioprotective function of clusterin and HDL, this difference may be among multiple contributors leading to higher cardiovascular risk in T2DM (Hoofnagle et al. 2010).

We have identified clusterin by low density Protein Array as one of the proteins being markedly increased in the adipose tissue of obese patients suggesting that it may also have a local regulatory role in adipose tissue and its metabolic changes in obesity. To this end, we measured mRNA expression of clusterin in adipose tissue and its plasma concentrations in obese patients with and without type 2 diabetes mellitus and explored its modulation by different intervention to gain further insight into its possible regulatory role in the adipose tissue.

\section{Methods}

\section{Study subjects and interventions}

This paper presents the data from three substudies. Fifteen obese women (OB group) and fifteen obese women with type 2 diabetes mellitus (T2DM group) who underwent a 2 -week very low-calorie diet (VLCD) with energy intake $2500 \mathrm{~kJ}$ per day (600 kcal per day) were included into the first substudy. During the reduction program all patients were hospitalized at the Third Department of Medicine, General University Hospital in Prague.

Ten obese women without T2DM who underwent laparoscopic sleeve gastrectomy (LSG; LSG-OB group) at the Surgical Clinic, Central Military Hospital in Prague, were included into the second substudy. The patients were referred to LSG based on the criteria recommended by European Obesity Society (Fried et al. 2013).

As a control group for the substudy one and two, fifteen healthy lean women (BMI $20-25 \mathrm{~kg} / \mathrm{m}^{2}$ ) were included.

Eight patients with T2DM (H-T2DM group), eight patients with impaired glucose tolerance (H-IGT group) and eight normoglycemic patients (H-NGT group) who underwent euglycemic hyperinsulinemic clamp (HEC) were included into the third substudy. Each group in this substudy consisted of 4 men and 4 women and all patients had BMI between 20 and $35 \mathrm{~kg} / \mathrm{m}^{2}$. HEC was initiated by continuous insulin infusion with the rate of $2 \mathrm{mIU} / \mathrm{kg} / \mathrm{min}$ for patients with $\mathrm{BMI}<30 \mathrm{~kg} / \mathrm{m}^{2}$ or $80 \mathrm{mIU} / \mathrm{m}^{2} / \mathrm{min}$ for patients with $\mathrm{BMI} \geq 30 \mathrm{~kg} / \mathrm{m}^{2}$. After 
$5 \mathrm{~min}$, the infusion rate was reduced by half and maintained at this level till the end of the test. Plasma glucose levels were measured every $5 \mathrm{~min}$ throughout the test. To achieve euglycemia, glucose infusion was started $5 \mathrm{~min}$ after the start of insulin infusion. The glucose infusion rate was adjusted during the test in order to achieve normoglycemia between 150 and $180 \mathrm{~min}$ of the test (steady state). As a measure of insulin sensitivity, Insulin Sensitivity Index $\left(\mathrm{MCR}_{\mathrm{glc}} / \mathrm{I}-\mathrm{ml} / \mathrm{kg} / \mathrm{min}\right.$ per $\mu \mathrm{IU} / \mathrm{ml}$ ) was calculated as the metabolic clearance rate for glucose $\left(\mathrm{MCR}_{\mathrm{glc}}, \mathrm{ml} / \mathrm{kg} / \mathrm{min}\right)$ divided by the mean insulin concentration during steady state.

The body weight of all study participants remained stable for at least three months before the enrollment into the study. Written informed consent was signed by all participants before beginning of the study. The study was approved by Human Ethical Review Committee, First Faculty of Medicine and General University Hospital, Prague, Czech Republic and was performed in accordance with the guidelines proposed in the Declaration of Helsinki.

Anthropometric examination, blood and adipose tissue sampling

Control subjects and subjects who underwent HEC were examined only once. Patients included in the reduction program (T2DM and $\mathrm{OB}$ group) were examined twice; at baseline and after 2 weeks of VLCD. Obese patients who underwent LSG (LSG-OB group) were examined three times; at baseline ( 1 week before LSG), 6 and 12 months after surgery.

All subjects were measured and weighted, and their BMI was calculated. Blood samples for biochemical and hormonal measurements were withdrawn after $12 \mathrm{~h}$ of overnight fasting. Blood samples were separated by centrifugation for $10 \mathrm{~min}$ at $1000 \mathrm{x}$ g within $30 \mathrm{~min}$ from blood collection. Serum and plasma samples were subsequently stored in aliquots at $-80^{\circ} \mathrm{C}$ until further analysis.

Samples of subcutaneous adipose tissue for mRNA expression analysis were obtained from abdominal region by subcutaneous needle aspiration biopsy. All samples were taken from approximately the same location. In HEC substudy, the samples were obtained $30 \mathrm{~min}$ before the start of HEC and $30 \mathrm{~min}$ after the end of HEC. Approximately $100 \mathrm{mg}$ of adipose tissue was collected to $1 \mathrm{ml}$ of RNA stabilization Reagent (RNAlater, Qiagen, Hilden, Germany) and stored at $-80^{\circ} \mathrm{C}$ until further analysis.

\section{Hormonal and biochemical assays}

Plasma clusterin levels were measured by a commercial ELISA kit (BioVendor, Brno, Czech Republic). Sensitivity was $0.5 \mathrm{ng} / \mathrm{ml}$, inter- and intraassay variability were $<7 \%$ and $<9 \%$, respectively.

Plasma leptin concentrations were measured by a commercial ELISA kit (BioVendor, Brno, Czech Republic) with a sensitivity $0.12 \mathrm{ng} / \mathrm{ml}$. Serum insulin concentrations were measured by commercial RIA kit (Cis Bio International, Gif-sur-Yvette Cedex, France) with a sensitivity $2.0 \mathrm{IU} / \mathrm{ml}$. Serum C-reactive protein (CRP) levels were measured by high sensitive assay (eBioscience, Vienna, Austria) with a sensitivity $3 \mathrm{pg} / \mathrm{ml}$. The intra- and interassay variabilities of all methods were less than $5 \%$ and less than $10 \%$, respectively.

Biochemical parameters (glucose, glycated hemoglobin, triglycerides, total and HDL cholesterol) were measured and LDL cholesterol was calculated in the Department of Biochemistry of General University Hospital by standard laboratory methods. The homeostasis model assessment index (HOMA-IR) was calculated using the following formula: (fasting serum insulin $(\mathrm{mIU} / \mathrm{l}) \times$ fasting serum glucose $(\mathrm{mmol} / \mathrm{l}) / 22.5$.

\section{Determination of mRNA expression}

Samples of subcutaneous adipose tissue were homogenized on a MagNA Lyser Instrument using MagNA Lyser Green Beads (Roche Diagnostics GmbH, Germany). Total RNA was extracted from the homogenized sample on MagNA Pure instrument using MagNA Pure Compact RNA Isolation (Tissue) kit (Roche Diagnostics GmbH, Germany). The RNA concentration was determined from absorbance at $260 \mathrm{~nm}$ and the integrity of RNA was controlled by $260 / 280 \mathrm{~nm}$ absorbance ratio (NanoPhotometer, Implen, Munchen, Germany). Reverse transcription was performed using $0.25 \mu \mathrm{g}$ of total RNA to synthesize the first strand cDNA using the random primers as per the instructions of the High-Capacity cDNA Reverse Transcription Kit (Applied Biosystems, Foster City, CA, USA).

Measurements of mRNA expression of clusterin and leptin were performed on an ABI PRISM 7500 instrument (Applied Biosystems, Foster City, CA, USA) using TaqMan $^{\circledR}$ Universal PCR Master Mix, NO AmpErase ${ }^{\circledR}$ UNG and specific TaqMan $^{\circledR}$ Gene Expression Assays (Applied Biosystems, Foster City, CA, USA) and nuclease-free water (Fermentas Life Science, Vilnius, Lithuania). The increase in fluorescence was measured in real time and threshold cycle (CT) 
values were obtained. To compensate for variations in the amount of RNA used and for the variable efficiency of reverse transcription, the target gene $\mathrm{CT}$ number was normalized to the endogenous control gene beta-2microglobulin and the formula $2^{- \text {ddCT }}$ was used to calculate relative mRNA expression. The results are expressed in arbitrary units.

Comparison of the amount of selected proteins in subcutaneous adipose tissue between control, obese and T2DM patients using low density Protein Array

Samples of subcutaneous adipose tissue were sonicated $10 \mathrm{~min}$ on ice-cold homogenization buffer [150 mM NaCl, $2 \mathrm{mM}$ EDTA, $10 \%$ glycerol, $25 \mathrm{mM}$ benzamidine, $1 \mathrm{mM}$ PMSF, and protease inhibitor cocktail (Sigma Aldrich, St. Louis, MO, USA) in $10 \mathrm{mM}$ Tris- $\mathrm{HCl}(\mathrm{pH}$ 7.0)]. The homogenate was centrifuged at $3,000 \mathrm{xg}$ for $15 \mathrm{~min}$ at $4{ }^{\circ} \mathrm{C}$, the fat cake was then discarded and the homogenate was centrifuged again at $14,000 \mathrm{x} \mathrm{g}$ for $20 \mathrm{~min}$ at $4{ }^{\circ} \mathrm{C}$. The supernatant was stored in aliquots at $-80^{\circ} \mathrm{C}$. Total amount of protein in each sample was assessed using the Bradford method with Bio-Rad Protein Assay (Bio-Rad Laboratories, Inc., Hercules, CA, USA) using BSA as a standard.

$350 \mu \mathrm{g}$ of total protein was transferred to each Human Apoptosis Antibody Array (R\&D System, Inc., Minneapolis, MN, USA) and array was processed according to the manufacturer instruction.

Detection of membrane antibody binding was evaluated by SuperSignal West Dura Chemiluminescent ECL Substrate (Pierce Biotechnology, Inc., Rockford, IL, USA). Signals were visualized and evaluated on a G:Box iChemi XT Bio instrument (Syngene, Cambridge, U.K.). Results were analyzed and the quantifications of bands were calculated using GeneTools Software (Syngene, Cambridge, U.K.).

For the pilot scan of 35 proteins in adipose tissue, samples from a control subject (age 51 years; BMI $23.3 \mathrm{~kg} / \mathrm{m}^{2}$ ), an obese subject without T2DM (age 60 years; BMI $50.0 \mathrm{~kg} / \mathrm{m}^{2}$ ) and an obese woman with T2DM before and after VLCD (age 49 years; BMI $74.6 \mathrm{~kg} / \mathrm{m}^{2}$ vs. $69.6 \mathrm{~kg} / \mathrm{m}^{2}$ ) were used.

\section{Statistical analysis}

Statistical analysis was performed on SigmaPlot 13.0 software (Systat Software, Inc., San Jose, CA,
USA). Prior to analysis, all continuous variables were assessed for normality. Anthropometric, hormonal and biochemical results are expressed as means \pm SEM (standard error of the means).

Differences between control group and obese and/or T2DM patients were evaluated using One way ANOVA vs. control group or Kruskal-Wallis one way analysis of variance on ranks with Multiple comparisons vs. control group (Holm-Sidak method or Dunn's method), as appropriate. Differences between values before and after the reduction program and mRNA expression before and after HEC were evaluated using Paired t-test or Wilcoxon signed rank test, as appropriate. Differences between values before and 6 and 12 months after LSG were evaluated using One way RM ANOVA with Fisher LSD method or its nonparametric version, according to the normality of data. Changes of plasma and serum concentrations during HEC vs. baseline were evaluated using Friedman repeated measures analysis of variance on ranks and Multiple comparisons vs. control group (Dunn's method).

To evaluate the associations between plasma clusterin or clusterin mRNA expression and other variables, Pearson or Spearman correlation test were used, according to the normality of data. Variables with $\mathrm{p}<0.05$ were further used for the Multiple linear regression analysis using Backward stepwise variable selection method.

Statistical significance for all tests was assigned to $p$ value $<0.05$.

\section{Results}

Difference in the amount of selected proteins in subcutaneous adipose tissue between control, obese and T2DM patients using low density Protein Array

For the pilot scan of 35 proteins in adipose tissue, samples of 1 patient in each group were used. As such, it was not possible to evaluate these data statistically.

After correction to positive controls, the detected amount of clusterin in the sample of SCAT from the obese patient was 9.92times higher and from the T2DM patient before VLCD 0.54times and after VLCD 1.36times higher compared with the control subject (Fig. 1). 
Table 1. Clinical, hormonal and metabolic characteristics of the control group and obese and T2DM patients before and after 2 weeks of VLCD.

\begin{tabular}{|c|c|c|c|c|c|}
\hline & Control & $\begin{array}{c}\text { OB } \\
\text { before VLCD }\end{array}$ & $\begin{array}{c}\text { OB } \\
\text { after VLCD }\end{array}$ & $\begin{array}{c}\text { T2DM } \\
\text { before VLCD }\end{array}$ & $\begin{array}{c}\text { T2DM } \\
\text { after VLCD }\end{array}$ \\
\hline No. of subjects (female/male) & $15(15 / 0)$ & $15(15 / 0)$ & $11(11 / 0)$ & $15(15 / 0)$ & $15(15 / 0)$ \\
\hline Age (years) & $49.3 \pm 1.7$ & $50.2 \pm 2.6$ & $\mathrm{X}$ & $55.8 \pm 1.6$ & $\mathrm{X}$ \\
\hline$B M I\left(\mathrm{~kg} / \mathrm{m}^{2}\right)$ & $23.9 \pm 0.6$ & $51.6 \pm 2.5^{\mathrm{C}}$ & $49.4 \pm 2.5^{\mathrm{CB}}$ & $52.0 \pm 2.6^{\mathrm{C}}$ & $49.4 \pm 2.4^{\mathrm{CB}}$ \\
\hline Body fat $(\mathrm{kg})$ & $20.8 \pm 1.6$ & $80.0 \pm 6.4^{\mathrm{C}}$ & $74.8 \pm 6.1^{\mathrm{CB}}$ & $74.3 \pm 5.7^{\mathrm{C}}$ & $69.5 \pm 5.0^{\mathrm{CB}}$ \\
\hline Waist circumference (cm) & $79.0 \pm 2.4$ & $131.6 \pm 4.1^{\mathrm{C}}$ & $127.8 \pm 4.3^{\mathrm{CB}}$ & $135.0 \pm 4.5^{\mathrm{C}}$ & $130.1 \pm 4.4^{\mathrm{CB}}$ \\
\hline Fasting blood glucose (mmol/l) & $4.82 \pm 0.09$ & $5.19 \pm 0.26$ & $4.69 \pm 0.14$ & $9.65 \pm 1.09^{\mathrm{CO}}$ & $7.84 \pm 0.66^{\mathrm{CO}}$ \\
\hline Glycated hemoglobin (\% IFCC) & $3.78 \pm 0.08$ & $4.27 \pm 0.16$ & $\mathrm{X}$ & $7.77 \pm 0.69^{\mathrm{CO}}$ & $X$ \\
\hline Total cholesterol ( $\mathrm{mmol} / \mathrm{l})$ & $5.39 \pm 0.28$ & $5.26 \pm 0.40$ & $4.21 \pm 0.39^{\mathrm{CB}}$ & $4.77 \pm 0.37$ & $3.77 \pm 0.22^{\mathrm{CB}}$ \\
\hline HDL cholesterol ( $\mathrm{mmol} / \mathrm{l})$ & $1.58 \pm 0.07$ & $1.37 \pm 0.11$ & $1.17 \pm 0.14^{\mathrm{CB}}$ & $1.12 \pm 0.06^{\mathrm{C}}$ & $0.95 \pm 0.04^{\mathrm{CB}}$ \\
\hline LDL cholesterol (mmol/l) & $3.31 \pm 0.21$ & $3.14 \pm 0.29$ & $2.49 \pm 0.29^{\mathrm{C}}$ & $2.72 \pm 0.31$ & $1.99 \pm 0.20^{\mathrm{CB}}$ \\
\hline Triglycerides (mmol/l) & $1.10 \pm 0.16$ & $1.66 \pm 0.27$ & $1.23 \pm 0.22$ & $2.22 \pm 0.34^{\mathrm{C}}$ & $1.86 \pm 0.19^{\mathrm{CO}}$ \\
\hline Fasting insulin $(\mu I U / m l)$ & $15.8 \pm 0.7$ & $43.6 \pm 7.4^{\mathrm{C}}$ & $34.9 \pm 5.1^{\mathrm{C}}$ & $53.6 \pm 11.3^{\mathrm{C}}$ & $44.3 \pm 4.7^{\mathrm{C}}$ \\
\hline HOMA-IR index & $3.39 \pm 0.18$ & $11.01 \pm 2.40^{\mathrm{C}}$ & $7.97 \pm 1.39$ & $22.93 \pm 4.70^{\mathrm{CO}}$ & $14.27 \pm 1.40^{\mathrm{CO}}$ \\
\hline$C R P(m g / l)$ & $0.194 \pm 0.056$ & $2.141 \pm 0.550^{\mathrm{C}}$ & $1.911 \pm 0.584^{\mathrm{CB}}$ & $2.497 \pm 0.361^{\mathrm{C}}$ & $1.775 \pm 0.294^{\mathrm{C}}$ \\
\hline Serum leptin $(n g / m l)$ & $14.3 \pm 2.1$ & $57.1 \pm 6.6^{\mathrm{C}}$ & $45.9 \pm 8.1^{\mathrm{CB}}$ & $58.6 \pm 5.1^{\mathrm{C}}$ & $54.8 \pm 6.1^{\mathrm{C}}$ \\
\hline Plasma clusterin $(\mu g / m l)$ & $77.2 \pm 7.7$ & $70.0 \pm 3.9$ & $60.3 \pm 5.2^{\mathrm{B}}$ & $63.8 \pm 2.8$ & $60.4 \pm 2.3$ \\
\hline$m R N A$ clusterin & $1.103 \pm 0.118$ & $1.894 \pm 0.197^{\mathrm{C}}$ & $1.676 \pm 0.136^{\mathrm{C}}$ & $2.046 \pm 0.118^{\mathrm{C}}$ & $1.888 \pm 0.206^{\mathrm{C}}$ \\
\hline$m R N A$ leptin & $1.144 \pm 0.136$ & $1.549 \pm 0.216$ & $1.655 \pm 0.177$ & $1.562 \pm 0.216$ & $1.635 \pm 0.191$ \\
\hline
\end{tabular}

Control - control group of healthy women, OB - obese women without type 2 diabetes mellitus, T2DM - obese women with type 2 diabetes mellitus. Values are means \pm SEM. Statistical significance is from One way ANOVA vs. control group, One Way RM ANOVA and paired t-test (see part Statistical analysis) or its nonparametric versions, as appropriate. ${ }^{\mathrm{C}} \mathrm{p}<0.05$ vs. control group; ${ }^{\circ} \mathrm{p}<0.05$ vs. obese patients, ${ }^{\mathrm{B}} \mathrm{p}<0.05$ vs. before VLCD.

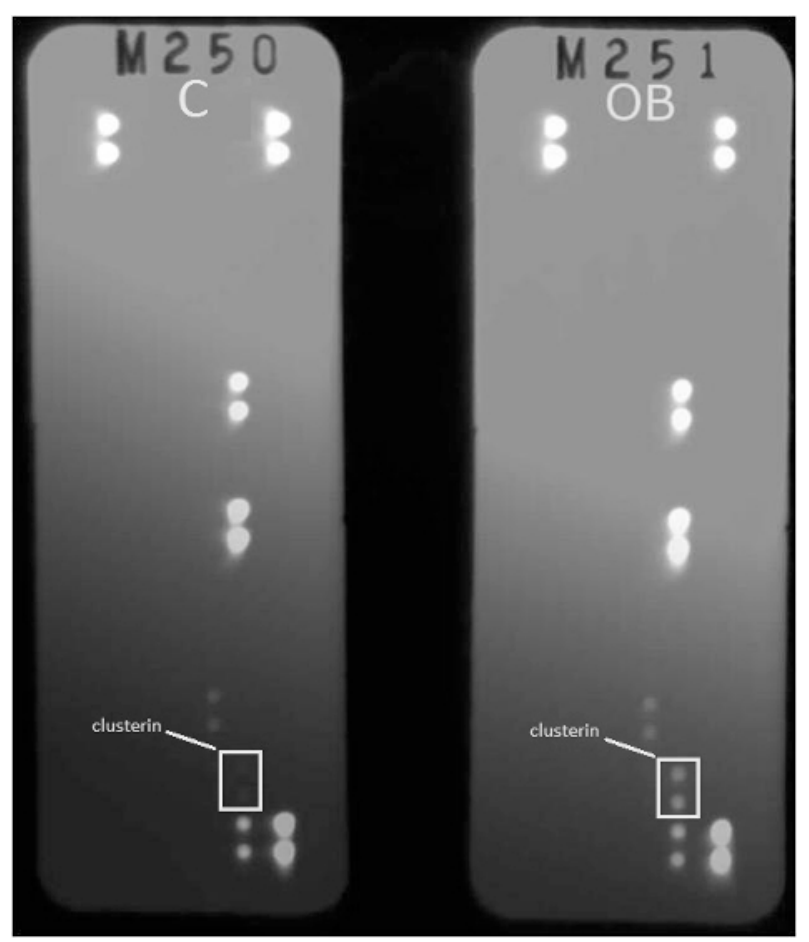

Fig. 1. Difference in amount of clusterin in the sample of control and obese patient on the low density Protein Array. C - control subject, $\mathrm{OB}$ - obese woman without type 2 diabetes mellitus.
The influence of VLCD on hormonal and biochemical parameters and $m R N A$ expression in T2DM and $O B$ patients

Clinical, hormonal and metabolic characteristics and mRNA expression of the control group and OB and T2DM patients before and after 2 weeks of VLCD are shown in Table 1. As expected, BMI, body fat, waist circumference, HOMA index, serum insulin, CRP and leptin concentrations were higher in both obese and T2DM group at baseline relative to control subjects. Fasting blood glucose, glycated hemoglobin and triglycerides were higher and HDL cholesterol was lower only in T2DM group relative to control subjects. There were no significant differences between the groups at baseline in the LDL and total cholesterol.

Two weeks of VLCD decreased BMI, waist circumference, HDL and total cholesterol in both obese and T2DM group, decreased body fat, CRP and leptin in obese group only and decreased LDL cholesterol in T2DM group only. Two weeks of VLCD did not influence fasting blood glucose, triglycerides and insulin 
levels. Relative gene mRNA expression of leptin did not differ between study groups at baseline and was not influenced by VLCD.

Plasma clusterin levels did not differ between OB, T2DM and control groups at baseline. Two weeks of VLCD decreased clusterin in the obese group whereas its levels in T2DM group were not influenced. Clusterin mRNA expression at baseline was higher in both $\mathrm{OB}$ and T2DM groups and remained elevated after VLCD. There were no significant differences in clusterin plasma levels and mRNA expression between OB and T2DM groups.

The effect of LSG on hormonal and biochemical parameters and $m R N A$ expression in obese non-diabetic patients

Clinical, hormonal and metabolic characteristics and mRNA expression of the control group and OB patients before and 6 and 12 months after LSG are shown in Table 2.

BMI, body fat, waist circumference, HDL cholesterol, fasting insulin, HOMA index, CRP and leptin concentrations were higher in obese group before laparoscopic sleeve gastrectomy (LSG) compared with control subjects. At baseline, there were no significant differences in glycated hemoglobin, triglycerides, LDL and total cholesterol.

Six months after LSG BMI, body fat, waist circumference, CRP and leptin levels were decreased. All these values remained decreased 12 months after LSG compared with baseline. Triglyceride levels were decreased and HDL cholesterol increased only 12 months after the LSG. Fasting blood glucose, glycated hemoglobin, total cholesterol, fasting insulin and HOMA index were not affected by LSG.

Plasma clusterin levels did not differ between obese and control groups at baseline and were not affected by LSG.

mRNA expression of both leptin and clusterin was higher in obese patients before LSG compared with control group. Clusterin mRNA remained elevated both 6 and 12 months after LSG, whereas leptin mRNA decreased 6 months after LSG to the levels comparable with control group while increasing again 12 months after LSG.

Table 2. Anthropometric, biochemical and hormonal characteristics of control group and obese non-diabetic subjects before, 6 months and 12 months after laparoscopic sleeve gastrectomy.

\begin{tabular}{|c|c|c|c|c|}
\hline & Control & $\begin{array}{c}\text { Obese before } \\
\text { LSG }\end{array}$ & $\begin{array}{c}\text { Obese } 6 \text { months } \\
\text { after LSG }\end{array}$ & $\begin{array}{c}\text { Obese } 12 \text { months } \\
\text { after LSG }\end{array}$ \\
\hline No. of subjects (female/male) & $15(15 / 0)$ & $10(10 / 0)$ & $10(10 / 0)$ & $10(10 / 0)$ \\
\hline Age (years) & $49.3 \pm 1.7$ & $40.6 \pm 2.6^{\mathrm{C}}$ & $\mathrm{X}$ & $\mathrm{X}$ \\
\hline$B M I\left(\mathrm{~kg} / \mathrm{m}^{2}\right)$ & $23.9 \pm 0.6$ & $43.3 \pm 2.7^{\mathrm{C}}$ & $33.4 \pm 1.9^{\mathrm{CB}}$ & $32.9 \pm 2.5^{\mathrm{CB}}$ \\
\hline Body fat $(\mathrm{kg})$ & $20.8 \pm 1.6$ & $60.5 \pm 7.2^{\mathrm{C}}$ & $39.4 \pm 4.5^{\mathrm{CB}}$ & $38.8 \pm 5.9^{\mathrm{CB}}$ \\
\hline Waist circumference (cm) & $79.0 \pm 2.4$ & $118.4 \pm 4.6^{\mathrm{C}}$ & $98.1 \pm 3.7^{\mathrm{CB}}$ & $97.1 \pm 5.2^{\mathrm{CB}}$ \\
\hline Fasting blood glucose (mmol/l) & $4.82 \pm 0.09$ & $4.97 \pm 0.22$ & $4.82 \pm 0.13$ & $4.86 \pm 0.12$ \\
\hline Glycated hemoglobin (\% IFCC) & $3.78 \pm 0.08$ & $3.91 \pm 0.22$ & $3.83 \pm 0.16$ & $3.60 \pm 0.12$ \\
\hline Total cholesterol (mmol/l) & $5.39 \pm 0.28$ & $5.22 \pm 0.31$ & $5.12 \pm 0.33$ & $5.04 \pm 0.49$ \\
\hline HDL cholesterol ( $\mathrm{mmol} / \mathrm{l})$ & $1.58 \pm 0.07$ & $1.26 \pm 0.13^{\mathrm{C}}$ & $1.37 \pm 0.13^{\mathrm{C}}$ & $1.53 \pm 0.19^{\mathrm{B}}$ \\
\hline LDL cholesterol ( $\mathrm{mmol} / \mathrm{l})$ & $3.31 \pm 0.21$ & $3.33 \pm 0.30$ & $3.16 \pm 0.28$ & $3.10 \pm 0.37$ \\
\hline Triglycerides (mmol/l) & $1.10 \pm 0.16$ & $1.53 \pm 0.15$ & $1.31 \pm 0.12$ & $1.10 \pm 0.12^{\mathrm{B}}$ \\
\hline Fasting insulin $(\mu I U / m l)$ & $15.8 \pm 0.7$ & $31.6 \pm 5.3^{\mathrm{C}}$ & $23.2 \pm 3.3$ & $23.1 \pm 4.3$ \\
\hline HOMA-IR index & $3.39 \pm 0.18$ & $7.25 \pm 1.50^{\mathrm{C}}$ & $5.01 \pm 0.72$ & $4.94 \pm 0.80$ \\
\hline$C R P(m g / l)$ & $0.194 \pm 0.056$ & $0.923 \pm 0.162^{\mathrm{C}}$ & $0.613 \pm 0.126^{\mathrm{CB}}$ & $0.499 \pm 0.168^{\mathrm{BA}}$ \\
\hline Serum leptin $(\mathrm{ng} / \mathrm{ml})$ & $14.3 \pm 2.1$ & $56.3 \pm 9.6^{\mathrm{C}}$ & $25.6 \pm 7.7^{\mathrm{B}}$ & $32.5 \pm 11.3^{\mathrm{B}}$ \\
\hline Plasma clusterin $(\mu g / m l)$ & $77.2 \pm 7.7$ & $75.6 \pm 7.3$ & $71.8 \pm 6.6$ & $71.4 \pm 5.7$ \\
\hline$m R N A$ clusterin & $1.103 \pm 0.118$ & $2.771 \pm 0.288^{\mathrm{C}}$ & $1.930 \pm 0.222^{\mathrm{CB}}$ & $2.145 \pm 0.294^{\mathrm{CB}}$ \\
\hline$m R N A$ leptin & $1.144 \pm 0.136$ & $2.233 \pm 0.298^{\mathrm{C}}$ & $1.451 \pm 0.160$ & $1.837 \pm 0.185^{\mathrm{C}}$ \\
\hline
\end{tabular}

Values are means \pm SEM. Statistical significance is from One way ANOVA vs. control group, One Way RM ANOVA and paired t-test (see part Statistical analysis) or its nonparametric versions, as appropriate. ${ }^{C} \mathrm{p}<0.05$ vs. control group; ${ }^{B}$ p $<0.05$ vs. obese patient before LSG; ${ }^{A} p<0.05$ vs. obese patient 6 months after LSG. 
The effect of euglycemic hyperinsulinemic clamp on hormonal and biochemical parameters and mRNA expression in NGT, IGT and T2DM patients

The clinical, hormonal and metabolic characteristics of the patients who underwent hyperinsulinemic euglycemic clamp (HEC) are shown in Table 3. There was no difference between the genders in basal plasma clusterin in the combined population of all patients $(52.3 \pm 3.4 \mathrm{ng} / \mathrm{ml}$ for males vs. $47.0 \pm 3.9 \mathrm{ng} / \mathrm{ml}$ for females; $p=0.322$ ). Similarly, there were no significant differences between groups in plasma clusterin during HEC (data not shown).

Compared with normoglycemic patients (NGT), the impaired glucose tolerance (IGT) and T2DM group had higher fasting blood glucose and HOMA index and were slightly older. In addition, T2DM group had higher glycated hemoglobin and HOMA index compared with NGT group and reduced HDL cholesterol compared with both NGT and IGT, whereas total cholesterol was lower compared with IGT group. There were no significant differences between groups in basal leptin.
Analogously, no significant differences between groups in the basal mRNA expression of clusterin and leptin could be observed. At the end of HEC, mRNA expression of clusterin was increased compared with baseline in the NGT group but not in the IGT and T2DM groups. mRNA expression of leptin was increased at the end of HEC compared with baseline in the IGT group but not in the NGT and T2DM patients (Table 3 ).

We did not find any significant relationships between plasma clusterin area under the curve or its mRNA expression and insulin sensitivity index (data not shown).

Relationship of plasma clusterin levels and its mRNA expression in SCAT to other studied parameters

The relationship of plasma clusterin levels and its mRNA expression in SCAT to other studied parameters was calculated in a combined population of healthy controls, OB, IGT and T2DM subjects at baseline and in the combined population consisting only of subjects with normal glucose tolerance (healthy controls and OB subjects at baseline) (Table 4).

Table 3. Clinical, hormonal and metabolic characteristics of the patients who underwent euglycemic hyperinsulinemic clamp.

\begin{tabular}{|c|c|c|c|}
\hline & NGT & IGT & T2DM \\
\hline No. of subjects (female/male) & $8(4 / 4)$ & $8(4 / 4)$ & $8(4 / 4)$ \\
\hline Age (years) & $55.0 \pm 1.5$ & $60.1 \pm 1.8^{\mathrm{N}}$ & $60.8 \pm 1.1^{\mathrm{N}}$ \\
\hline$B M I\left(\mathrm{~kg} / \mathrm{m}^{2}\right)$ & $28.6 \pm 1.4$ & $29.8 \pm 1.0$ & $29.7 \pm 1.3$ \\
\hline Body fat $(\mathrm{kg})$ & $25.1 \pm 4.1$ & $27.3 \pm 2.9$ & $30.3 \pm 3.2$ \\
\hline Waist circumference (cm) & $91.1 \pm 4.5$ & $99.8 \pm 2.6$ & $102.8 \pm 3.1$ \\
\hline Fasting blood glucose ( $\mathrm{mmol} / \mathrm{l})$ & $4.91 \pm 0.17$ & $5.92 \pm 0.24^{\mathrm{N}}$ & $7.08 \pm 0.36^{\mathrm{NI}}$ \\
\hline Glycated hemoglobin (\% IFCC) & $4.06 \pm 0.13$ & $4.31 \pm 0.10$ & $4.79 \pm 0.14^{\mathrm{N}}$ \\
\hline Total cholesterol $(\mathrm{mmol} / \mathrm{l})$ & $5.30 \pm 0.31$ & $5.62 \pm 0.36$ & $4.42 \pm 0.27^{\mathrm{I}}$ \\
\hline HDL cholesterol (mmol/l) & $1.64 \pm 0.15$ & $1.57 \pm 0.10$ & $1.12 \pm 0.12^{\mathrm{NI}}$ \\
\hline LDL cholesterol (mmol/l) & $3.22 \pm 0.19$ & $3.33 \pm 0.28$ & $2.61 \pm 0.12$ \\
\hline Triglycerides (mmol/l) & $0.99 \pm 0.08$ & $2.01 \pm 0.56$ & $2.20 \pm 0.56$ \\
\hline Fasting insulin $(\mu I U / m l)$ & $13.4 \pm 1.7$ & $27.2 \pm 4.8$ & $31.3 \pm 7.1$ \\
\hline$H O M A-I R$ index & $2.97 \pm 0.48$ & $6.84 \pm 0.88^{\mathrm{N}}$ & $9.34 \pm 2.66^{\mathrm{N}}$ \\
\hline$C R P(m g / l)$ & $0.690 \pm 0.337$ & $1.148 \pm 0.265$ & $1.212 \pm 0.523$ \\
\hline Insulin Sensitivity Index ( $\mathrm{ml} / \mathrm{kg} / \mathrm{min}$ per $\mu \mathrm{IU} / \mathrm{ml})$ & $0.022 \pm 0.003$ & $0.015 \pm 0.002$ & $0.009 \pm 0.002^{\mathrm{N}}$ \\
\hline Serum leptin $(\mathrm{ng} / \mathrm{ml})$ & $9.7 \pm 2.8$ & $16.0 \pm 5.1$ & $33.1 \pm 8.2$ \\
\hline Basal plasma clusterin $(\mu \mathrm{g} / \mathrm{ml})$ & $41.1 \pm 3.0$ & $54.0 \pm 2.9$ & $53.9 \pm 5.8$ \\
\hline$m R N A$ leptin - before HEC & $1.554 \pm 0.277$ & $1.167 \pm 0.142$ & $1.420 \pm 0.188$ \\
\hline mRNA leptin - after HEC & $1.799 \pm 0.247$ & $1.649 \pm 0.231^{\mathrm{B}}$ & $1.705 \pm 0.201$ \\
\hline mRNA clusterin - before HEC & $1.760 \pm 0.200$ & $1.591 \pm 0.136$ & $1.696 \pm 0.141$ \\
\hline$m R N A$ clusterin - after HEC & $2.041 \pm 0.256^{\mathrm{B}}$ & $1.845 \pm 0.224$ & $1.921 \pm 0.164$ \\
\hline
\end{tabular}

NGT - normoglycemic group, IGT - group with impaired glucose tolerance, T2DM - group with type 2 diabetes mellitus. Values are means \pm SEM. Statistical significance is from paired t-test and One way ANOVA or its nonparametric version, as appropriate. ${ }^{\mathrm{N}} \mathrm{p}<0.05$ vs. NGT; ${ }^{\mathrm{I}} \mathrm{p}<0.05$ vs. IGT, ${ }^{\mathrm{B}} \mathrm{p}<0.05$ vs. before HEC. 
Table 4. The relationship of serum clusterin levels and its mRNA expression in SCAT to other studied parameters.

\begin{tabular}{|c|c|c|c|c|c|c|c|c|}
\hline & \multicolumn{4}{|c|}{ Plasma clusterin $(\mu \mathrm{g} / \mathrm{ml})$} & \multicolumn{4}{|c|}{ mRNA clusterin } \\
\hline & \multicolumn{2}{|c|}{$\mathrm{C}+\mathrm{NGT}+\mathrm{OB}$} & \multicolumn{2}{|c|}{$\begin{array}{c}\mathrm{C}+\mathrm{NGT}+\mathrm{OB}+ \\
\mathrm{IGT}+\mathrm{T} 2 \mathrm{DM} \\
\end{array}$} & \multicolumn{2}{|c|}{$\mathrm{C}+\mathrm{NGT}+\mathrm{OB}$} & \multicolumn{2}{|c|}{$\begin{array}{c}\mathrm{C}+\mathrm{NGT}+\mathrm{OB}+ \\
\mathrm{IGT}+\mathrm{T} 2 \mathrm{DM}\end{array}$} \\
\hline & $\mathbf{R}$ & $\mathbf{p}$ & $\mathbf{R}$ & $\mathbf{p}$ & $\mathbf{R}$ & $\mathbf{p}$ & $\mathbf{R}$ & $\mathbf{p}$ \\
\hline Age (years) & -0.200 & 0.167 & -0.287 & 0.010 & -0.263 & 0.063 & -0.193 & 0.086 \\
\hline$B M I\left(\mathrm{~kg} / \mathrm{m}^{2}\right)$ & 0.147 & 0.314 & 0.254 & 0.023 & 0.455 & $<0.001$ & 0.473 & $<0.001$ \\
\hline Body fat (kg) & 0.228 & 0.114 & 0.284 & 0.011 & 0.444 & 0.001 & 0.466 & $<0.001$ \\
\hline Waist circumference (cm) & 0.155 & 0.287 & 0.216 & 0.054 & 0.452 & $<0.001$ & 0.468 & $<0.001$ \\
\hline Fasting blood glucose (mmol/l) & 0.131 & 0.369 & -0.103 & 0.363 & 0.136 & 0.341 & 0.121 & 0.283 \\
\hline Glycated hemoglobin (\% IFCC) & -0.073 & 0.624 & -0.092 & 0.422 & 0.063 & 0.670 & 0.161 & 0.161 \\
\hline Total cholesterol (mmol/l) & 0.133 & 0.361 & 0.178 & 0.117 & 0.036 & 0.804 & 0.006 & 0.957 \\
\hline HDL cholesterol $(\mathrm{mmol} / \mathrm{l})$ & -0.123 & 0.402 & -0.008 & 0.948 & -0.274 & 0.054 & -0.220 & 0.053 \\
\hline LDL cholesterol (mmol/l) & 0.076 & 0.608 & 0.149 & 0.198 & -0.008 & 0.954 & -0.010 & 0.931 \\
\hline Triglycerides (mmol/l) & 0.221 & 0.126 & 0.150 & 0.187 & 0.445 & 0.001 & 0.375 & $<0.001$ \\
\hline Fasting insulin $(\mu I U / m l)$ & 0.313 & 0.046 & 0.237 & 0.055 & 0.515 & $<0.001$ & 0.443 & $<0.001$ \\
\hline HOMA-IR index & 0.303 & 0.054 & 0.159 & 0.203 & 0.491 & $<0.001$ & 0.401 & $<0.001$ \\
\hline$C R P(m g / l)$ & 0.117 & 0.441 & 0.090 & 0.453 & 0.410 & 0.004 & 0.273 & 0.021 \\
\hline Leptin $(n g / m l)$ & 0.224 & 0.138 & 0.268 & 0.023 & 0.561 & $<0.001$ & 0.543 & $<0.001$ \\
\hline Plasma clusterin $(\mu \mathrm{g} / \mathrm{ml})$ & $\mathrm{X}$ & $\mathrm{X}$ & $\mathrm{X}$ & $\mathrm{X}$ & -0.039 & 0.798 & 0.040 & 0.735 \\
\hline mRNA leptin & -0.133 & 0.388 & 0.031 & 0.796 & 0.743 & $<0.001$ & 0.684 & $<0.001$ \\
\hline
\end{tabular}

C - lean controls, NGT - normoglycemic group, OB - obese patients without T2DM, IGT - impaired glucose tolerance group, T2DM group with type 2 diabetes mellitus. $C+N G T+O B+I G T+T 2 D M: n=80 ; C+N G T+O B: n=51$. Values are means $\pm S E M$. Statistical significance is from Spearman Rank Order Correlation test. $p<0.05$ was assed as statistical significant.

Plasma clusterin correlated positively with BMI, body fat and leptin and inversely with age in the combined group including IGT and T2DM patients but not in the group without IGT and T2DM patients. On the contrary, plasma clusterin correlated positively with fasting insulin only in the combined group without IGT and T2DM patients.

In both combined groups (with or without T2DM patients) mRNA clusterin correlated positively with BMI, body fat, waist circumference, serum triglycerides, fasting insulin, HOMA index, CRP, leptin and leptin mRNA in SCAT.

We could not find a correlation between plasma clusterin and plasma leptin or between plasma clusterin and mRNA clusterin in SCAT.

According to the multiple linear regression model, none of the parameters included was an independent predictor of plasma clusterin levels in a combined group without T2DM and IGT patients. Plasma clusterin levels in the combined group of all patients, including T2DM and IGT, could be predicted only from one independent variable - age with $\mathrm{p}=0.004$ and the adjusted $R^{2}=0.099$. The clusterin mRNA levels in both combined groups could be predicted from a linear combination of two independent variables - leptin mRNA expression $(\mathrm{p}<0.001)$ and waist circumference $(\mathrm{p}<0.001)$ and the adjusted $\mathrm{R}^{2}$ was 0.645 for the group without T2DM and IGT and 0.598 for the group of all patients.

\section{Discussion}

We have identified clusterin by low density Protein Array as one of the proteins being markedly increased in the adipose tissue of obese patients suggesting that it may also have a local regulatory role in adipose tissue and its metabolic changes in obesity. To this end, we measured its mRNA expression and plasma concentrations in obese patients with and without type 2 diabetes mellitus and explored its modulation by different interventions to gain further insight into its possible regulatory role in the adipose tissue.

In our study, we found no significant differences in circulating clusterin levels between controls, obese and 
T2DM patients what would indicate that clusterin does not have a systemic role in the etiopathogenesis of metabolic complications of obesity. Our results are in agreement with those of Poulakou et al. (2008) who found similar levels of plasma clusterin in diabetic and non-diabetic patients with the same BMI and also with those of Arnold and colleagues (2011) who did not find any difference between obese and normal weight adolescents. On the contrary, other studies found increased plasma clusterin levels in obese and T2DM patients (Trougakos et al. 2002, Won et al. 2014).

In our previous studies, we have demonstrated the beneficial effect of various weight reduction methods on the metabolic and proinflammatory profile of obese patients both with and without type 2 diabetes mellitus (Mraz et al. 2011, Touskova et al. 2012, Urbanova et al. 2014). In this study, we investigated whether very-lowcalorie diet (VLCD) and laparoscopic sleeve gastrectomy (LSG) affect plasma clusterin concentrations or its mRNA expression in subcutaneous adipose tissue in obese patients with or without T2DM. We found a marked decrease in plasma clusterin after 2 weeks of VLCD in obese but interestingly not in T2DM patients. The reason for this differential response is not clear. One of the possible explanations could be the fact that metabolic derangements in patients with obesity and type 2 diabetes are more profound and a shorter intervention with very-low-calorie diet was not sufficient enough to induce complete systemic changes (Galgani et al. 2008). Alternatively, considering the similar direction of difference and comparable post-interventional plasma clusterin levels in both groups, the absence of a clear effect of VLCD in T2DM subjects could be the result of a relatively small number of patients in the group. Nevertheless, the lack of changes in plasma clusterin concentrations after LSG argues against its direct regulation by weight reducing interventions or against its significant role in the modulation of energy homeostasis.

Along the same lines, we were not able to find any correlation between plasma clusterin and BMI, body fat or waist circumference in the combined group of patients without IGT and T2DM. This is in agreement with some of the previous studies (Arnold et al. 2011, Kujiraoka et al. 2006, Poulakou et al. 2008) which also did not find any relationship between circulating clusterin and BMI. In our study, we also examined sex-dependent differences in plasma clusterin levels. The study by Poulakou and colleagues (2008) showed higher levels of clusterin in male compared with female subjects. In our study we did not find any gender differences, which could have been due to the relatively low number of subjects included or their different characteristics as compared to Poulakou's study.

According to the available data, about 40-60\% of clusterin in circulating blood is supposed to be part of the HDL particle, where it is bound to apolipoprotein-A1 (James et al. 1991, Jenne et al. 1991). It also could be part of the low density lipoprotein (LDL) (Hoofnagle et al. 2010, Pettersson et al. 2011). There is a strong inverse relationship between the amount of clusterin in HDL and in LDL/VLDL (Hoofnagle et al. 2010). With respect to these data it is interesting to note, that we did not find any correlation between plasma clusterin and HDL or LDL cholesterol. Clusterin probably also creates complexes with leptin and acts as a regulator of leptin activity, although the importance of this mechanism is controversial (Arnold et al. 2011, Bajari et al. 2003). In our study, we found only a weak correlation of plasma clusterin with plasma leptin in the combined group of all patients and no correlation in the group without IGT and T2DM subjects. This result is in accordance with the results of Arnold and colleagues (2011) who also did not find any such relationship.

To our best knowledge, no information regarding the clusterin mRNA expression in adipose tissue is currently available. In our study, clusterin mRNA expression in SCAT was increased compared with control group in both OB and T2DM groups and remained increased after 2 weeks of VLCD. On the contrary, 6 months after LSG clusterin mRNA expression was decreased by $30 \%$ compared with baseline and remained lower by $23 \%$ even 12 months after LSG. In other tissues, clusterin was identified as the gene whose increased expression could indicate the repair or remodeling of damaged tissue (Hoofnagle et al. 2010, Jenne et al. 1991). One of the consequences of obesity is increased rate of apoptosis and cell death in adipose tissue. In vivo, clusterin expression appears to be associated with cell survival (Humphreys et al. 1999). It is therefore tempting to speculate that increased mRNA expression of clusterin in adipose tissue in obese patients could be the marker of a compensatory mechanism protecting the tissue against apoptosis as a result of weight-reducing interventions. This possibility is also supported by the fact that in the multiple linear regression model clusterin mRNA expression in SCAT could be predicted from leptin mRNA expression together with waist circumference. 
One of the proposed roles of clusterin bound with HDL cholesterol is its beneficial influence on atherosclerosis, since the lack of clusterin in HDL particles impairs the lipoprotein's cardioprotective functions (Hoofnagle et al. 2010, James et al. 1991). Increased amount of clusterin was found in arterial wall during the development of atherosclerosis (Trougakos et al. 2002). Clusterin in the HDL complex probably serves as a regulator of lipid transport and local lipid redistribution but not as the molecule transporting lipids itself (Jenne et al. 1991, Trougakos et al. 2002).

One of the primary actions of clusterin could be the repression of inflammation (Kounnas et al. 1995), although the evidence in support of this idea is not clear. According to the study of Shim and colleagues (2012) clusterin upregulates expression of chemotactic cytokines as e.g. monocyte chemotactic protein-1 and induces the migration of macrophages both directly and by the induction of TNF- $\alpha$. On the other hand, clusterin was found to reduce the expression of TNF- $\alpha$ in vivo and clusterin-deficient mice showed enhanced infiltration of inflammatory cells during pancreatitis (Savkovic et al. 2007). Moreover, clusterin overexpression attenuates the expression of proinflammatory chemokines (Kim et al. 2009) and in the model of clusterin deficient mice it limits the progression of autoimmune myocarditis and protects the heart from postinflammatory tissue destruction (McLaughlin et al. 2000). Thus we could hypothesize that clusterin might have an anti-inflammatory function also in adipose tissue, which role could be another explanation for its elevated mRNA expression in subcutaneous adipose tissue of obese patients that is typically characterized by chronic low-grade inflammation. This idea is also supported by the fact that in our study clusterin mRNA expression in SCAT of both combined groups with or without T2DM patients correlated positively not only with markers of obesity (BMI, body fat, waist circumference) but also with serum triglycerides, fasting insulin, HOMA index and the inflammatory marker CRP. Chronic lowgrade inflammation in obese subject is one of the mechanisms contributing to the development of atherosclerosis and thus the anti-inflammatory effect of clusterin could also be protection against atherosclerosis. On the contrary, the fact that ApoE-KO mice with decreased expression of nuclear clusterin have reduced atherosclerotic lesions argues against its antiatherosclerotic role (Hamada et al. 2011).

While a strong positive correlation between clusterin levels in HDL particles and insulin sensitivity was found in humans (Hoofnagle et al. 2010), little is known about the acute regulatory role of insulin and glucose in the changes of clusterin mRNA expression. In the primary hepatocytes and hepatoma cell lines, high glucose concentrations increased clusterin expression (Kim et al. 2011). To assess the effect of insulin and glucose levels on plasma levels and mRNA expression of clusterin in SCAT, we performed a hyperinsulinemic euglycemic clamp (HEC). We could not find any significant changes in plasma clusterin levels during HEC in any of the studied groups or any relationship between plasma clusterin area under the curve or its mRNA expression and insulin sensitivity index. mRNA expression of clusterin was elevated at the end of HEC compared with baseline only in the normoglycemic group, but not in the IGT or T2DM group. The explanation of this phenomenon remains unclear and warrants further investigations.

In summary, plasma clusterin concentrations did not differ between healthy subjects and obese patients with or without type 2 diabetes mellitus and they were only partially influenced by short-term weight reduction. On the contrary, clusterin mRNA expression in subcutaneous fat was higher in obese and T2DM patients compared with lean controls and it decreased after bariatric surgery but not after short-term caloric restriction. Clusterin mRNA correlated positively with markers of obesity, serum triglycerides, fasting insulin, HOMA index and the inflammatory marker CRP. Taken together, our data suggest a possible local regulatory role for clusterin in the adipose tissue rather than its systemic involvement in the regulation of energy homeostasis.

\section{Conflict of Interest}

There is no conflict of interest.

\section{Acknowledgements}

Supported by RVO VFN64165, IGA NT13299-4 and AZV 15-26854A.

\section{References}

ARNOLD T, BRANDLHOFER S, VRTIKAPA K, STANGL H, HERMANN M, ZWIAUER K, MANGGE H, KARWAUTZ A, HUEMER J, KOLLER D, SCHNEIDER WJ, STROBL W: Effect of obesity on plasma clusterin, [corrected] a proposed modulator of leptin action. Pediatr Res 69: 237-242, 2011. 
ARONOW BJ, LUND SD, BROWN TL, HARMONY JA, WITTE DP: Apolipoprotein J expression at fluid-tissue interfaces: potential role in barrier cytoprotection. Proc Natl Acad Sci U S A 90: 725-729, 1993.

BAJARI TM, STRASSER V, NIMPF J, SCHNEIDER WJ: A model for modulation of leptin activity by association with clusterin. FASEB J 17: 1505-1507, 2003.

BLASCHUK O, BURDZY K, FRITZ IB: Purification and characterization of a cell-aggregating factor (clusterin), the major glycoprotein in ram rete testis fluid. J Biol Chem 258: 7714-7720, 1983.

CHOI-MIURA NH, IHARA Y, FUKUCHI K, TAKEDA M, NAKANO Y, TOBE T, TOMITA M: SP-40,40 is a constituent of Alzheimer's amyloid. Acta Neuropathol 83: 260-264, 1992.

FRIED M, YUMUK V, OPPERT JM, SCOPINARO N, TORRES AJ, WEINER R, YASHKOV Y, FRUHBECK G, EUROPEAN ASSOCIATION FOR THE STUDY OF OBESITY, INTERNATIONAL FEDERATION FOR THE SURGERY OF OBESITY - EUROPEAN CHAPTER: Interdisciplinary European Guidelines on metabolic and bariatric surgery. Obes Facts 6: 449-468, 2013.

FRITZ IB, BURDZY K, SETCHELL B, BLASCHUK O: Ram rete testis fluid contains a protein (clusterin) which influences cell-cell interactions in vitro. Biol Reprod 28: 1173-1188, 1983.

GALGANI JE, HEILBRONN LK, AZUMA K, KELLEY DE, ALBU JB, PI-SUNYER X, SMITH SR, RAVUSSIN E, LOOK AHEAD ADIPOSE RESEARCH GROUP: Metabolic flexibility in response to glucose is not impaired in people with type 2 diabetes after controlling for glucose disposal rate. Diabetes 57: 841-845, 2008.

HAMADA N, MIYATA M, ETO H, IKEDA Y, SHIRASAWA T, AKASAKI Y, MIYAUCHI T, FURUSHO Y, NAGAKI A, ARONOW BJ, TEI C: Loss of clusterin limits atherosclerosis in apolipoprotein E-deficient mice via reduced expression of Egr-1 and TNF-alpha. $J$ Atheroscler Thromb 18: 209-216, 2011.

HOOFNAGLE AN, WU M, GOSMANOVA AK, BECKER JO, WIJSMAN EM, BRUNZELL JD, KAHN SE, KNOPP RH, LYONS TJ, HEINECKE JW: Low clusterin levels in high-density lipoprotein associate with insulin resistance, obesity, and dyslipoproteinemia. Arterioscler Thromb Vasc Biol 30: 2528-2534, 2010.

HUMPHREYS DT, CARVER JA, EASTERBROOK-SMITH SB, WILSON MR: Clusterin has chaperone-like activity similar to that of small heat shock proteins. J Biol Chem 274: 6875-6881, 1999.

JAMES RW, HOCHSTRASSER AC, BORGHINI I, MARTIN B, POMETTA D, HOCHSTRASSER D: Characterization of a human high density lipoprotein-associated protein, NA1/NA2. Identity with SP-40,40, an inhibitor of complement-mediated cytolysis. Arterioscler Thromb 11: 645-652, 1991.

JENNE DE, LOWIN B, PEITSCH MC, BOTTCHER A, SCHMITZ G, TSCHOPP J: Clusterin (complement lysis inhibitor) forms a high density lipoprotein complex with apolipoprotein A-I in human plasma. $J$ Biol Chem 266: 11030-11036, 1991.

KIM G, KIM GH, OH GS, YOON J, KIM HW, KIM MS, KIM SW: SREBP-1c regulates glucose-stimulated hepatic clusterin expression. Biochem Biophys Res Commun 408: 720-725, 2011.

KIM HJ, YOO EK, KIM JY, CHOI YK, LEE HJ, KIM JK, JEOUNG NH, LEE KU, PARK IS, MIN BH, PARK KG, LEE CH, ARONOW BJ, SATA M, LEE IK: Protective role of clusterin/apolipoprotein J against neointimal hyperplasia via antiproliferative effect on vascular smooth muscle cells and cytoprotective effect on endothelial cells. Arterioscler Thromb Vasc Biol 29: 1558-1564, 2009.

KOUNNAS MZ, LOUKINOVA EB, STEFANSSON S, HARMONY JA, BREWER BH, STRICKLAND DK, ARGRAVES WS: Identification of glycoprotein 330 as an endocytic receptor for apolipoprotein J/clusterin. J Biol Chem 270: 13070-13075, 1995.

KUJIRAOKA T, HATTORI H, MIWA Y, ISHIHARA M, UENO T, ISHII J, TSUJI M, IWASAKI T, SASAGURI Y, FUJIOKA T, SAITO S, TSUSHIMA M, MARUYAMA T, MILLER IP, MILLER NE, EGASHIRA T: Serum apolipoprotein $\mathrm{J}$ in health, coronary heart disease and type 2 diabetes mellitus. $J$ Atheroscler Thromb 13: 314-322, 2006.

MCLAUGHLIN L, ZHU G, MISTRY M, LEY-EBERT C, STUART WD, FLORIO CJ, GROEN PA, WITT SA, KIMBALL TR, WITTE DP, HARMONY JA, ARONOW BJ: Apolipoprotein J/clusterin limits the severity of murine autoimmune myocarditis. $J$ Clin Invest 106: 1105-1113, 2000.

MRAZ M, LACINOVA Z, DRAPALOVA J, HALUZIKOVA D, HORINEK A, MATOULEK M, TRACHTA P, KAVALKOVA P, SVACINA S, HALUZIK M: The effect of very-low-calorie diet on mRNA expression of inflammation-related genes in subcutaneous adipose tissue and peripheral monocytes of obese patients with type 2 diabetes mellitus. J Clin Endocrinol Metab 96: E606-E613, 2011. 
OBERBACH A, BLUHER M, WIRTH H, TILL H, KOVACS P, KULLNICK Y, SCHLICHTING N, TOMM JM, ROLLE-KAMPCZYK U, MURUGAIYAN J, BINDER H, DIETRICH A, VON BERGEN M: Combined proteomic and metabolomic profiling of serum reveals association of the complement system with obesity and identifies novel markers of body fat mass changes. J Proteome Res 10: 4769-4788, 2011.

PETTERSSON C, KARLSSON H, STAHLMAN M, LARSSON T, FAGERBERG B, LINDAHL M, WIKLUND O, BOREN J, FOGELSTRAND L: LDL-associated apolipoprotein J and lysozyme are associated with atherogenic properties of LDL found in type 2 diabetes and the metabolic syndrome. J Intern Med 269: 306-321, 2011.

POULAKOU MV, PARASKEVAS KI, WILSON MR, ILIOPOULOS DC, TSIGRIS C, MIKHAILIDIS DP, PERREA $\mathrm{D}$ : Apolipoprotein $\mathrm{J}$ and leptin levels in patients with coronary heart disease. In Vivo 22: 537-542, 2008.

SAVKOVIC V, GANTZER H, REISER U, SELIG L, GAISER S, SACK U, KLOPPEL G, MOSSNER J, KEIM V, HORN F, BODEKER H: Clusterin is protective in pancreatitis through anti-apoptotic and anti-inflammatory properties. Biochem Biophys Res Commun 356: 431-437, 2007.

SHIM YJ, KANG BH, CHOI BK, PARK IS, MIN BH: Clusterin induces the secretion of TNF-alpha and the chemotactic migration of macrophages. Biochem Biophys Res Commun 422: 200-205, 2012.

SONG F, POLJAK A, CRAWFORD J, KOCHAN NA, WEN W, CAMERON B, LUX O, BRODATY H, MATHER K, SMYTHE GA, SACHDEV PS: Plasma apolipoprotein levels are associated with cognitive status and decline in a community cohort of older individuals. PLoS One 7: e34078, 2012.

TOUSKOVA V, TRACHTA P, KAVALKOVA P, DRAPALOVA J, HALUZIKOVA D, MRAZ M, LACINOVA Z, MAREK J, HALUZIK M: Serum concentrations and tissue expression of components of insulin-like growth factor-axis in females with type 2 diabetes mellitus and obesity: the influence of very-low-calorie diet. Mol Cell Endocrinol 361: 172-178, 2012.

TROUGAKOS IP, POULAKOU M, STATHATOS M, CHALIKIA A, MELIDONIS A, GONOS ES: Serum levels of the senescence biomarker clusterin/apolipoprotein $\mathrm{J}$ increase significantly in diabetes type II and during development of coronary heart disease or at myocardial infarction. Exp Gerontol 37: 1175-1187, 2002.

URBANOVA M, DOSTALOVA I, TRACHTA P, DRAPALOVA J, KAVALKOVA P, HALUZIKOVA D, MATOULEK M, LACINOVA Z, MRAZ M, KASALICKY M, HALUZIK M: Serum concentrations and subcutaneous adipose tissue mRNA expression of omentin in morbid obesity and type 2 diabetes mellitus: the effect of very-low-calorie diet, physical activity and laparoscopic sleeve gastrectomy. Physiol Res 63: 207-218, 2014.

WON JC, PARK CY, OH SW, LEE ES, YOUN BS, KIM MS: Plasma clusterin (ApoJ) levels are associated with adiposity and systemic inflammation. PLoS One 9: e103351, 2014.

ZERRAD-SAADI A, THEROND P, CHANTEPIE S, COUTURIER M, RYE KA, CHAPMAN MJ, KONTUSH A: HDL3-mediated inactivation of LDL-associated phospholipid hydroperoxides is determined by the redox status of apolipoprotein A-I and HDL particle surface lipid rigidity: relevance to inflammation and atherogenesis. Arterioscler Thromb Vasc Biol 29: 2169-2175, 2009. 